\title{
A Practical Culture Technique for Enhanced Production of Manganese Peroxidase by Anthracophyllum discolor Sp4
}

\author{
Francisca Acevedo ${ }^{1,4}$, Leticia Pizzul ${ }^{2}$, María del Pilar Castillo ${ }^{3}$, Olga Rubilar ${ }^{4}$, María Elena \\ Lienqueo $^{5}$, Gonzalo Tortella ${ }^{4}$ and María Cristina Diez ${ }^{4 *}$ \\ ${ }^{1}$ Universidad de La Frontera; P. O. Box 54-D; Temuco - Chile. ${ }^{2}$ Uppsala BioCenter; Department of Microbiology; \\ Swedish University of Agricultural Sciences; P. O. Box 7025; SE-750 07; Uppsala - Sweden. ${ }^{3}$ JTI - Swedish Institute \\ of Agricultural and Environmental Engineering; P. O. Box 7033; SE-750 07; Uppsala - Sweden. ${ }^{4}$ Scientifical and \\ Technological Bioresource Nucleus; Department of Chemical Engineering; Universidad de La Frontera; PO Box \\ 54-D; Temuco - Chile. ${ }^{5}$ Department of Chemical and Biotechnology Engineering; Faculty of Physical and \\ Mathematical Sciences; University of Chile; Beauchef, 850; Santiago - Chile
}

\begin{abstract}
In this study, different growth conditions of Anthracophyllum discolor Sp4 including the effect of agitation, additions of lignocellulosic support, inducer and surfactant were evaluated on the MnP production in Kirk medium using a culture system made up of the tubes containing the glass bead. The highest MnP production (1,354 U/L on day 13) was obtained when the medium was supplemented with wheat grain and $0.25 \mathrm{mM} \mathrm{MnSO}_{4}$ as inducer, under static conditions at $30^{\circ} \mathrm{C}$. Two isoenzymes were purified ( 35 and $38 \mathrm{kDa}$ respectively). MnP presented a maximal activity in the $\mathrm{pH}$ range between 4.5 and 5.5 , a relatively high temperature tolerance $\left(50^{\circ} \mathrm{C}\right)$ and a high catalytic activity for 2,6-dimethoxyphenol and hydrogen peroxide.
\end{abstract}

Key words: white-rot fungi; ligninolytic enzymes, purification, lignocellulosic material

\section{INTRODUCTION}

Global population growth, urbanization and industrialization have caused environmental contamination by the organic compounds. Microorganisms play an important role in removing, transforming, or mineralizing the xenobiotic compounds to less toxic form (Whiteley and Lee, 2006). White-rot fungi, which are responsible for the biodegradation of lignin present in the wood, offer valuable ecological and metabolic characteristics that make them useful in the bioremediation processes (Pointing, 2001). These microorganisms have a remarkable ability to transform and even mineralize a large spectrum of organic compounds (Rabinovich et al, 2003). This is due to their characteristic enzymatic system, which is comprised of non-specific extracellular oxidative enzymes such as lignin peroxidase $(\mathrm{LiP})$, manganese peroxidase $(\mathrm{MnP})$ and laccase (L) produced during the secondary metabolism (Pointing, 2001).

Optimal culture conditions are required for high enzyme yields because the efficient pollutant degradation is mainly correlated with the high enzymatic activities. Furthermore, practical and efficient culture systems for the fungal biodegradation tests are required. An efficient

*Author for correspondence: mcdiez@ufro.cl 
culture system depends on many factors that can contribute to high enzymatic yields in white-rot fungi. Fungal MnP production can be enhanced by the substrate/support, e.g., lignocellulosic materials such as poplar, or fir sawdust (Giardina et al, 2000), grape seeds, barley bran and wood shavings (Moredo et al, 2003). The enhancement of MnP production and stimulation of enzymatic activity by the white-rot fungi have been observed following the addition of inducers such as $\mathrm{MnSO}_{4}$ (Gill and Arora, 2003) and cosubstrates such as Tween 80 (Watanabe et al, 2000; Garon et al, 2002). The expression of $\mathrm{MnP}$ in the fungal cultures is dependent on $\mathrm{Mn}$, which regulates the mnp gene transcription (Ma et al, 2004). Tween 80 can transform the cell membrane structure and thereby promote the permeation of $\mathrm{MnP}$ from the cell into the medium and the solubility of the contaminants (Zheng and Obbard, 2002).

Ligninolytic enzymes have been purified, characterized and used as biocatalysts in the biodegradation of pollutants. Over the past few years, a great deal of attention has been paid to the potential use of $\mathrm{MnP}$ in biobleaching of pulp and paper and for xenobiotic compounds degradation because of the characteristics of its catalytic cycle (Eibes et al, 2002; Wariishi et al, 1992).

Anthracophyllum discolor $\mathrm{Sp} 4$ is a Chilean whiterot fungus isolated from the decayed wood in the rain forest of southern Chile (Tortella et al, 2008). This fungus has a potential for degradation of organic pollutants because of its high production of ligninolytic enzymes, especially $\mathrm{MnP}$ (Rabinovich et al, 2003; Rubilar et al, 2007), and can thus be used in bioremediation systems.

It is necessary to test the ability of $A$. discolor $\mathrm{Sp} 4$ to degrade various pollutants before designing the bioremediation systems. Biodegradation tests require the analyses of large numbers of samples over the time, which can be difficult to manage in terms of space, rational use of the chemicals, extraction efficiency, etc., especially using the Erlenmeyer flasks as culture system. In addition, the biodegradation tests normally require destructive sampling (complete destruction of sample for the analysis), particularly when the target compound is hydrophobic, or is applied at the concentrations where it is insoluble in the growth medium. A practical and simple culture technique using the tubes containing the glass beads has been used for the study of polycyclic aromatic hydrocarbon (PAHs) degradation by the actinobacteria (Pizzul et al, 2006) and could be of interest in the fungal cultures.

The purpose of this study was to study the effect of $\mathrm{Mn}^{2+}$, Tween 80 and lignocellulosic substrate on $\mathrm{MnP}$ production by $A$. discolor $\mathrm{Sp} 4$ and to evaluate a simple and practical culture system for $\mathrm{MnP}$ production using the tubes containing the glass beads as replacement of Erlenmeyer flasks.

\section{MATERIALS AND METHODS}

\section{Chemicals}

2,6-DMP (2,6-dimethoxyphenol) (> 99.0\%) was supplied by the Aldrich Chemical Co., Germany. 3,4-dimethoxy-benzyl alcohol (> 95.0\%) was supplied by the Fluka. All other chemicals were supplied by the Merck, Oxoid, Sigma and Duchefa (Netherlands).

\section{Microorganism}

The fungal strain used was Anthracophyllum discolor $\mathrm{Sp} 4$ isolated from decayed wood in the rain forest of southern Chile (culture collection of the Environmental Biotechnology Laboratory at the Universidad de La Frontera, Chile). The fungus was stored at $4^{\circ} \mathrm{C}$ in glucose malt extract agar (G-MEA) slants containing (g/L) malt extract 30 , agar 15 and glucose 10 . The fungus was transferred from the slant culture tubes to Petri dishes with G-MEA medium and incubated at $30^{\circ} \mathrm{C}$ for 5 days.

\section{MnP production by A. discolor Sp4 in liquid medium supplemented with wheat grain}

Five malt agar plugs $(6 \mathrm{~mm}$ diameter $)$ of active mycelia of A. discolor Sp4 from 5-day-old cultures on G-MEA medium were inoculated in $100 \mathrm{~mL}$ of Kirk medium (Tien and Kirk, 1988) in an 1-L Erlenmeyer flask. The Kirk medium contained the following (g/L): glucose 10 , peptone $2, \mathrm{KH}_{2} \mathrm{PO}_{4}$ $2, \mathrm{MgSO}_{4} 0.5, \mathrm{CaCl}_{2} 0.1$ and, thiamine $2 \mathrm{mg} / \mathrm{L}$ and mineral salts $10 \mathrm{~mL} / \mathrm{L}$ (which contained in $\mathrm{g} / \mathrm{L}$ $\mathrm{KH}_{2} \mathrm{PO}_{4} 2, \mathrm{MgSO}_{4} \cdot 7 \mathrm{H}_{2} \mathrm{O} 0.5, \mathrm{CaCl}_{2} \cdot 2 \mathrm{H}_{2} \mathrm{O} 0.1$, and in $\mathrm{mg} / \mathrm{L}, \mathrm{MnSO}_{4} 5 \mathrm{H}_{2} \mathrm{O} 50, \mathrm{NaCl} 10$, $\mathrm{FeSO}_{4} \cdot 7 \mathrm{H}_{2} \mathrm{O} 1.0, \mathrm{CoCl}_{2} 6 \mathrm{H}_{2} \mathrm{O} 1.0, \mathrm{ZnSO}_{4} \cdot 7 \mathrm{H}_{2} \mathrm{O}$ $1.0, \mathrm{CuSO}_{4} 5 \mathrm{H}_{2} \mathrm{O} 0.1, \mathrm{AlK}\left(\mathrm{SO}_{4}\right)_{2} 0.1, \mathrm{H}_{3} \mathrm{BO}_{3} 0.1$ , $\mathrm{NaMoO}_{4} 2 \mathrm{H}_{2} \mathrm{O}$ 0.1). Sterile wheat grains (32 g) were added to the medium and the fungus was grown without agitation. Cultures containing $A$. discolor Sp4 grown in Kirk medium without wheat grain under then static conditions, or on a shaker at 
$100 \mathrm{rpm}$ were used as the controls. The cultures were incubated at $30^{\circ} \mathrm{C}$ for 28 days. Samples were taken periodically and $\mathrm{MnP}$ activity, proteolytic activity, total protein concentration and $\mathrm{pH}$ were ascertained.

Effect of $\mathrm{MnSO}_{4}$ and/or Tween 80 on $\mathrm{MnP}$ production by A. discolor Sp4 grown in liquid medium supplemented with wheat grain

In order to evaluate the effect of $\mathrm{MnSO}_{4}$ for $\mathrm{MnP}$ production, Kirk medium (100 mL) containing $0.002 \mathrm{mM} \mathrm{MnSO}_{4}$ as trace element and supplemented with $32 \mathrm{~g}$ of sterile wheat grain was modified by adding various concentrations of monohydrated manganese sulfate $\left(\mathrm{MnSO}_{4} \mathrm{H}_{2} \mathrm{O}\right)$ in order to obtain its $0.002,0.25,0.5,1.0$ and $2.0 \mathrm{mM}$ concentration. The medium was inoculated as described above and the flasks were incubated at $30^{\circ} \mathrm{C}$ under static conditions for 28 days. The MnP activity was determined periodically. In order to evaluate the effect of Tween 80 on the MnP production, $100 \mathrm{~mL}$ of Kirk medium supplemented with $32 \mathrm{~g}$ of sterile wheat grain and $0.25 \mathrm{mM}$ of $\mathrm{MnSO}_{4} \mathrm{H}_{2} \mathrm{O}$, was modified by adding Tween 80 $(0.05 \% \mathrm{v} / \mathrm{v})$ and inoculated as described above. The flasks were incubated at $30^{\circ} \mathrm{C}$ under static conditions for 28 days. A control flask without Tween 80 was run in parallel. The MnP activity was determined periodically.

Cultivation suitability of $\mathrm{A}$. discolor $\mathrm{Sp4}$ for MnP production in the tubes containing glass beads

A. discolor Sp4 was cultivated in three culture media using two culture techniques, $100-\mathrm{mL}$ Erlenmeyer flasks and $50-\mathrm{mL}$ tubes containing 20 $\mathrm{g}$ of sterile glass beads ( $5 \mathrm{~mm}$ diameter) in Kirk medium. The Erlenmeyer flasks and tubes contained 20 and $10 \mathrm{~mL}$, respectively of the following media: a) modified Kirk medium containing $0.25 \mathrm{mM} \mathrm{MnSO}_{4} \mathrm{H}_{2} \mathrm{O}$, b) modified Kirk medium containing $0.25 \mathrm{mM} \mathrm{MnSO}_{4} \mathrm{H}_{2} \mathrm{O}$ and sterile wheat grain $(0.32 \mathrm{~g} / \mathrm{mL})$, and c) modified Kirk medium containing $0.25 \mathrm{mM}$ $\mathrm{MnSO}_{4} \mathrm{H}_{2} \mathrm{O}$, sterile wheat grain $(0.32 \mathrm{~g} / \mathrm{L})$ supplemented with $0.05 \% \mathrm{v} / \mathrm{v}$ of Tween 80 . The media were inoculated with active mycelia of $A$. discolor $\mathrm{Sp} 4$ from 5-day-old cultures on G-MEA medium (one plug/10 $\mathrm{mL}$ medium). Incubation was carried out at $30^{\circ} \mathrm{C}$ under static conditions for 29 days. The MnP activity in the supernatant of the fungal culture samples was monitored periodically by $2,6-\mathrm{DMP}$ method. The values reported are the average of three samples with their standard deviation.

Statistical analysis was performed using a Student's $t$-test for the independent paired data for comparing the culture techniques on the production of $\mathrm{MnP}$ by $A$. discolor $\mathrm{Sp} 4$ growing in various media. Differences between the mean values at $p \leq 0.05$ were considered to be significant.

\section{MnP purification}

A. discolor Sp4 was grown under the optimized culture conditions from which $\mathrm{MnP}$ was subsequently purified. The mycelium was separated from the culture medium by filtration through a membrane filter Whatman $(0.45 \mu \mathrm{m})$. The filtrate was concentrated by ultrafiltration with the Amicon tubes $(10 \mathrm{kDa})$ at $4^{\circ} \mathrm{C}$, and the enzyme purification was carried out using FPLC (Fast Protein Liquid Chromatograph, Amersham Pharmacia Sweden). The concentrate was applied to a $1-\mathrm{mL}$ column $\mathrm{Q}$ Sepharose, which had been equilibrated with $20 \mathrm{mM}$ piperazine $(\mathrm{pH}$ 5.0). Elution of the proteins was achieved by a 1 $\mathrm{mL} / \mathrm{min}$ linear gradient from $0-2 \mathrm{M} \mathrm{NaCl}$ with 20 $\mathrm{mM}$ piperazine $\mathrm{pH}$ 5.0. The fractions containing the enzyme were concentrated by the Amicon tubes $(10 \mathrm{kDa})$ and then loaded to a GFC-100 gel filtration column. This column was equilibrated and eluted with $20 \mathrm{mM}$ piperazine ( $\mathrm{pH}$ 5.0) buffer with $100 \mathrm{mM} \mathrm{NaCl}$. The gradient was isocratic and the flow was $1 \mathrm{~mL} / \mathrm{min}$. Specific activity was determined by the ratio of total activity to protein content. The purification yield was evaluated by the ratio between the total activity for each step and the initial one. The fold purification was calculated by the ratio between the specific activities at each purification step. All the steps during the purification were performed at $4^{\circ} \mathrm{C}$.

\section{Enzyme characterization}

The apparent Michaelis-Menten constant $\mathrm{K}_{\mathrm{M}}$ of the purified MnP was determined by LineweaverBurk plots of activity versus the substrate profiles for 2,6-DMP in the range of $10-2,000 \mu \mathrm{M}$ concentration and for $\mathrm{H}_{2} \mathrm{O}_{2}$ in the range of $40-$ $2,400 \mu \mathrm{M}$ concentration. The enzymatic activity of the purified $\mathrm{MnP}$ was determined at various $\mathrm{pH}$ $(\mathrm{pH} 3-9)$ at $30^{\circ} \mathrm{C}$ after $15 \mathrm{~min}$ of incubation. The buffer solutions used were $150 \mathrm{mM}$ sodium tartrate solution $\mathrm{pH} 3.0,150 \mathrm{mM}$ sodium malonate solution $\mathrm{pH} 4.5$ and $5.5,150 \mathrm{mM}$ Tris- $\mathrm{HCl}$ solution $\mathrm{pH} 6.5,7.5,8.0$ and 9.0. The enzymatic 
activity of the purified $\mathrm{MnP}$ was determined at various temperatures between 25 and $70^{\circ} \mathrm{C}$ after 15 min of incubation. The activation energy (Ea) was calculated by plotting the log of activities of the purified manganese peroxidase versus $1 / \mathrm{T}$ (in $\mathrm{K}$ ) according to the Arrhenius equation. The value of activation energy was obtained by a computed linear regression analysis of the experimental data (Rao and Gianfreda, 2000). Enzyme thermostability was determined by incubating the purified $\mathrm{MnP}$ at different temperatures (40, 50, 60 and $70^{\circ} \mathrm{C}$ ) in sodium malonate solution $(\mathrm{pH} 4.5)$ for $2 \mathrm{~h}$.

The molecular mass of the purified $\mathrm{MnP}$ was determined using the SDS-PAGE electrophoresis (Laemmi, 1970) with the Protein III apparatus, Biorad. Protein bands were visualized with silver nitrate solution. The molecular mass marker used was the broad range protein molecular weight marker from the Promega. The presence of MnP bands were confirmed using a non-denaturing electrophoresis (zymogram analysis). The samples were applied in non-reducing denaturizing loading buffer without boiling. The gels were incubed in $50 \mathrm{mM}$ sodium malonate $(\mathrm{pH} 4.5)$ and $1 \mathrm{mM}$ $\mathrm{MnSO}_{4}$ for $1 \mathrm{~h}$ and then stained for the MnP activity with a solution containing the same solution supplemented with $1 \mathrm{mM}$ of 2,6-DMP and the oxidative agent $0.4 \mathrm{mM} \quad \mathrm{H}_{2} \mathrm{O}_{2}$. Bands were stained orange, the characteristic color of MnP activity.

\section{Analyses}

\section{Enzyme assays}

The manganese peroxidase activity in the supernatant of the fungal culture sample (after centrifugation for $10 \mathrm{~min}$ at $5,000 \mathrm{rpm}$ ) was determined by monitoring the oxidation of 2,6DMP spectrophotometrically at $30^{\circ} \mathrm{C}$. The purified $\mathrm{MnP}$ activity was also determined by the 2,6-DMP method.

2,6-DMP assay: the reaction mixture $(1.0 \mathrm{~mL})$ contained $200 \mu \mathrm{L}$ of $250 \mathrm{mM}$ sodium malonate (pH 4.5), $50 \mu \mathrm{L}$ of $20 \mathrm{mM}$ 2,6-DMP, $50 \mu \mathrm{L}$ of 20 $\mathrm{mM} \mathrm{MnSO} \mathrm{H}_{4} \mathrm{H}_{2} \mathrm{O}$, and $600 \mu \mathrm{L}$ of supernatant. The reaction was initiated by adding $100 \mu \mathrm{L}$ of $4 \mathrm{mM}$ $\mathrm{H}_{2} \mathrm{O}_{2}$ and the absorbance of the colored product was measured at $468 \mathrm{~nm}$ and corrected for the laccase activity (Wariishi et al, 1992). One MnP activity unit (U) was defined as the amount of enzyme transforming $1 \mu \mathrm{mol}$ 2,6-DMP per minute at $\mathrm{pH} 4.5$ and $30^{\circ} \mathrm{C}$ (Wariishi et al, 1992).
Protease activity was measured using the Rowley and Bull method (1977). The supernatant of the samples was incubated with azocasein $(2.5 \mathrm{~g} / \mathrm{L})$ at $37^{\circ} \mathrm{C}$ for 20 minutes. The protease activity was stopped by the precipitation of proteins with 2.0 $\mathrm{mL}$ of $2 \mathrm{M}$ trichloroacetic acid. The precipitated proteins were eliminated by centrifugation and the change in color produced by the protease activity on the azocasein in the supernatant was measured at $400 \mathrm{~nm}$. The activity was expressed in units (U) where one unit equals $1 \%$ azocasein hydrolysis in 20 min.

\section{Protein concentration}

Protein concentration in the supernatant of the fungal culture sample (after centrifugation for 10 min at 5,000 rpm) was determined using the Bradford method (1976) with crystalline bovine serum albumin (BSA) as the protein standard. Protein content in the purified $\mathrm{MnP}$ also was determined using the Bradford method. The supernatant $(1.0 \mathrm{~mL})$ was added to $3.0 \mathrm{~mL}$ of Bradford reagent (Biorad) and mixed by gentle vortex.The absorbance of the sample was measured at $595 \mathrm{~nm}$ using an ultraviolet-visible spectrophotometer against the Bradford reagent blank between $2 \mathrm{~min}$ and $1 \mathrm{~h}$ after the mixing. The amount of protein was quantified by comparing the absorbance with a standard curve. The values reported are the average of three samples with their standard deviation.

\section{RESULTS AND DISCUSSION}

\section{MnP production by A. discolor Sp4 in liquid} medium supplemented with wheat grain

The addition of wheat grain to the static culture of A. discolor Sp4 produced an increase in $\mathrm{MnP}$ activity (Fig. 1) compared to the controls (without wheat grain, with or without agitation). $\mathrm{MnP}$ activity reached the maximum value of $1,100 \mathrm{U} / \mathrm{L}$ after 13 days of growth, which was 3.8-fold higher than the control under static conditions and 8.6 times higher than the control with agitation (Fig. 1 ). The results were in agreement with those reports in which higher ligninolytic activities were detected when the lignocellulosic material was used as a substrate for fungal growth. The activity of MnP in Pleurotus ostreatus cultures with poplar sawdust was eight times higher than in the cultures with fir sawdust (Giardina et al, 2000). The 
production of ligninolytic enzymes by Phanerochaete chrysosporium and Trametes versicolor grown with different lignocellulosic materials increased in relation to the control (without lignocellulosic material), particularly with barley and grape residues (Moredo et al, 2003). White-rot fungi normally grow on the decaying wood and forest litter. They degrade the cellulose and lignin by the means of their extracellular enzymatic system, which suggests that the lignocellulosic substrates as energy source are suitable for their growth. The immobilization of the mycelium on the surface of wheat grains provided a better surface area and increased the mass transfer, thus improving the production of the enzymes (Herpoël et al, 1999). Moreover, the fungal mycelium may penetrate the lignocellulose support, releasing additional water-soluble aromatic/phenolic substances, which in turn may induce the secretion of the ligninolytic enzymes (Kapich et al, 2004).

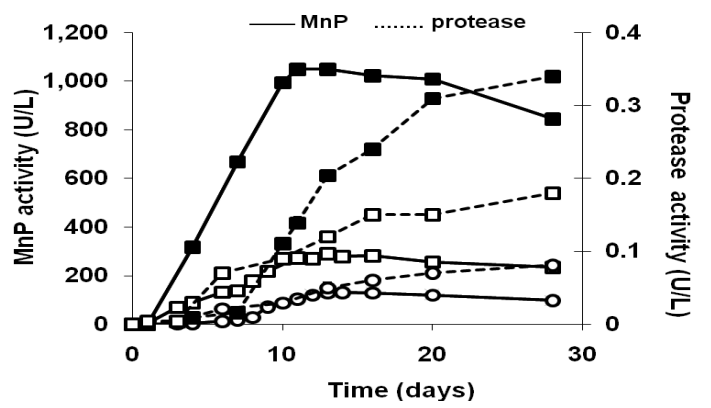

Figure 1 - Manganese peroxidase (-) and protease (....) activity (U/L) in A. discolor Sp4 cultures growing in modified Kirk medium (ם) supplemented with wheat grain and static conditions, ( $\square$ ) without wheat grain, under static conditions, ( $\circ)$ without wheat grain, on a shaker at $100 \mathrm{rpm}$.

Low MnP activity was observed in the agitated cultures. Venkatadri and Irvine (1990) reported that the formation of mycelia pellets and $\mathrm{O}_{2}$ limitation, shear stress of mycelia and denaturation of enzymes at high agitation speeds (100 to 200 $\mathrm{rpm})$ were some explanations to this loss of activity. The loss in the enzyme activity has been well-correlated to the degree of agitation, as described by Venkatadri and Irvine (1990) for ligninases. Therefore, static cell cultures are desirable for the $\mathrm{MnP}$ production due to the increase in the contact area between the cells and oxygen without shear stress (Ürek and Pazarlioğlu, 2007).

With the addition of wheat grain, the proteases activity was higher than the controls (without wheat grain, under static conditions, or on a shaker at $100 \mathrm{rpm}$ ) and reached $0.20 \mathrm{U} / \mathrm{L}$ after 13 days. Under the static conditions, the protease activity in the control without agitation increased 2-fold on the $13^{\text {th }}$ day in comparison with the agitated control, reaching a maximum value of $0.12 \mathrm{U} / \mathrm{L}$ (Fig. 1).

Some authors have reported that the total glucose consumption by the white-rot fungi in Kirk medium leads to protease production as a consequence of cell lysis, which affects the ligninolytic enzyme production (Staszczak et al, 2000). In the presentstudy, the MnP reached a maximum activity on day 13 , followed by a significant increase in the protease activity when using wheat grain (Fig. 1), suggesting a metabolic shift from lignin and cellulose to protein and carbohydrate degradation. In the absence of wheat grain, A. discolor Sp4 produced the proteases (for peptone degradation) without showing a substantial MnP activity (Fig. 1).

In spite of higher protease production when wheat grain was used as a substrate, maximal $\mathrm{MnP}$ activity increased when compared with the results for the Kirk medium. This led to consider the use of wheat grains as substrate to be beneficial for enhanced MnP production, usable for the future studies of organic pollutants degradation by $A$. discolor Sp4.

The protein concentration was higher than the controls in the presence of wheat grain, reaching $225 \mathrm{mg} / \mathrm{L}$ after 13 days of growth (Fig. 2). In the control (without wheat grains, under static conditions), the total protein concentration increased from $6 \mathrm{mg} / \mathrm{L}$ on day 6 to $40 \mathrm{mg} / \mathrm{L}$ on day 
13. Under agitation, the maximum total protein concentration was $6 \mathrm{mg} / \mathrm{L}$ (Fig. 2).

The increase in the total protein concentration (Fig. 2) correlated to the MnP activity (Fig. 1) as a response to the growth of A. discolor Sp4. Sato et al (2007) have identified a large number of proteins from $P$. chrysosporium grown on different liquid and solid substrates involved in the carbohydrate, lignin and protein metabolism. Van den Wymelenberg et al (2006) analyzed the $P$. chrysosporium genome, identifying 769 proteins within the secretosome, including the cell wallbound and endoplasmic reticulum (ER)-related proteins.

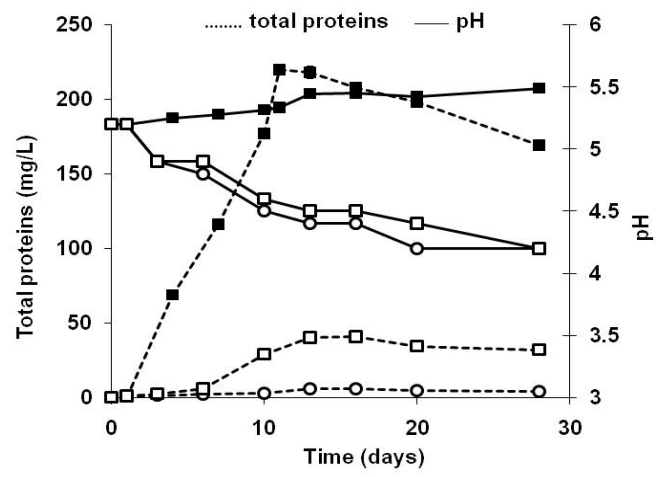

Figure 2 - Total proteins (.....) and $\mathrm{pH}(-)$ in A. discolor $\mathrm{Sp} 4$ cultures growing in modified Kirk medium ( $\square$ ) supplemented with wheat grain, under static conditions, ( $\square$ ) without wheat grain, under static conditions, $(\circ)$ without wheat grain, on a shaker at $100 \mathrm{rpm}$.

The presence of wheat grain slightly increased the $\mathrm{pH}$ in the culture medium from 5.2 to 5.5 (Fig. 2). This could be attributed to the presence of ammonium in the medium, which was produced by the use of amino acids and proteins of wheat grain. The $\mathrm{pH}$ in the culture medium without wheat grains (with and without agitation) decreased from 5.2 to 4.2 after 28 days (Fig. 2). This was probably due to the secretion of organic acids, such as oxalic, formic and glyoxylic acids (Dutton et al, 1996; 1996; Mäkelä et al, 2002). Physiological concentrations of oxalic acid have been shown to stimulate the MnP activity by chelating the unstable $\mathrm{Mn}^{3+}$ (Kuan and Tien, 1993). MnP can generate $\mathrm{H}_{2} \mathrm{O}_{2}$ by the oxidation of oxalic and glyoxylic acids, thus providing an endogenous source for extracellular $\mathrm{H}_{2} \mathrm{O}_{2}$ (Urzúa et al, 1998).

The $\mathrm{pH}$ ranges obtained in this study were adequate for the growth of white-rot fungi since they generally grew at $\mathrm{pH} 4.0-6.0$, with an optimum for enzyme production between 4.5 and 5.0 (Ürek and Pazarlioğlu, 2007).

Effect of $\mathrm{MnSO}_{4}$ and Tween 80 on $\mathrm{MnP}$ production by A. discolor Sp4 in liquid medium supplemented with wheat grain

The addition of 0.25 to $1 \mathrm{mM} \mathrm{MnSO}_{4} \mathrm{H}_{2} \mathrm{O}$ increased the production of $\mathrm{MnP}$ by $\mathrm{A}$. discolor
Sp4 in the culture medium in the presence of wheat grain (Fig. 3). The maximum MnP activity $(1,400 \mathrm{U} / \mathrm{L})$ was obtained after 8 days of incubation with the addition of $0.25 \mathrm{mM}$ of $\mathrm{MnSO}_{4} \mathrm{H}_{2} \mathrm{O}$. The highest concentration of $\mathrm{MnSO}_{4} \mathrm{H}_{2} \mathrm{O}(2.0 \mathrm{mM})$ added showed an inhibitory effect on the fungus growth and MnP production. In this treatment, a small mycelium growth was observed as compared to the other cultures supplemented with lower amounts of $\mathrm{MnSO}_{4} \mathrm{H}_{2} \mathrm{O}$. Moreover, the supernatant of this culture appeared turbid and darkened to brown after 8 days. This color could be attributed to the formation of a $\mathrm{MnO}_{2}$ precipitate when $\mathrm{Mn}^{3+}$ was oxidized in the presence of an insufficient organic acid level in the medium (Rogalski et al, 2006). The enzymatic activity of $\mathrm{MnP}$ requires manganese to function. However, high concentrations of manganese can inhibit the enzyme due to the generation of large quantities of hydrogen peroxide that inhibit the catabolic cycle of the enzyme (Wariishi et al, 1988; Bermek et al, 2002). In fact, hydrogen peroxide is known to be a product of numerous enzymatic reactions by the means of aryl alcohol oxidase, glyoxal oxidase action and ligninolytic enzymes (Gómez-Toribio et al, 2001). In addition, $\mathrm{H}_{2} \mathrm{O}_{2}$ is produced by the non-enzymatic reactions involving certain metals and metal complexes that have been shown to catalyze the reaction for the 
$\mathrm{H}_{2} \mathrm{O}_{2}$ production. $\mathrm{Mn}^{2+}$ reduces the superoxide to $\mathrm{H}_{2} \mathrm{O}_{2}$ and is oxidized to $\mathrm{Mn}^{3+}$ (Schlosser et al, 2002). At high concentrations of hydrogen peroxide, MnP II is converted to an inactive form (MnP III), not involved in the normal catalytic cycle (Mester and Tien, 2000). As a result, the amount of fungal biomass and the mycelia growth of the fungi are affected as well (Rothschild et al, 1999).

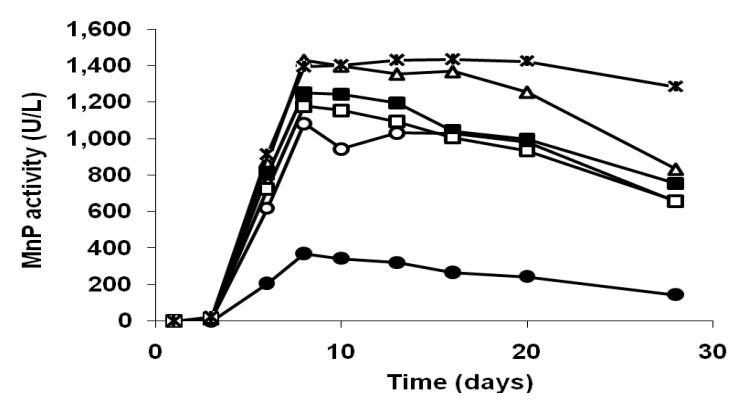

Figure 3 - Manganese peroxidase (MnP) activity (U/L) in modified Kirk medium inoculated with A. discolor Sp4 supplemented with wheat grain and (०) $0.002(\Delta) 0.25$ (匹) 0.5 (口) 1.0 (•) $2.0 \mathrm{mM}$ of $\mathrm{MnSO}_{4},\left(^{*}\right) 0.25 \mathrm{mM}$ of $\mathrm{MnSO}_{4}$ and $0.05 \% \mathrm{v} / \mathrm{v}$ Tween 80 , at $30^{\circ} \mathrm{C}$ under static conditions.

In the present study, the addition of $0.05 \%(\mathrm{v} / \mathrm{v})$ Tween 80 maintained a high and constant level of the enzyme for 28 days (Fig. 3). Ürek and Pazarlioğlu (2005) observed that Tween 80 at $0.05 \%$ (v/v) would act as an inducer of $\mathrm{MnP}$ production from $P$. chrysosporium. The addition of surfactants such as Tween 80 would have a regulatory effect on the production of ligninolytic enzymes, especially for MnP (Garon et al, 2002; Watanabe et al, 2000). Surfactants also may modify the plasma membrane, altering the transport of compounds in and out of the cell, or protect against the mechanical inactivation of the enzymes (Venkatadri and Irvine, 1990). However, a high concentration of surfactants could have an inhibiting effect on the fungal growth and ligninolytic enzymes production (Zhou et al, 2007). The mechanism by which the surfactants such as Tween 80 increase the extracellular enzyme production has not been established.

Cultivation suitability of A. discolor Sp4 for MnP production in tubes containing glass beads A. discolor $\mathrm{Sp} 4$ showed significant growth in the tubes containing the glass beads coating the hyphae at the bottom of the tube and favoring interaction between the fungus and the medium for enhancing the $\mathrm{MnP}$ production. Using this culture system, the volume of the samples was considerably reduced and each tube was used to perform the corresponding analysis without altering the assay (destructive sampling). This could be relevant for biodegradation assays over the time, when it is important to carry out several experiments in parallel managing a large number of samples in terms of space.

Table 1 shows the MnP production from $A$. discolor $\mathrm{Sp} 4$ grown in Erlenmeyer flasks, or tubes containing the glass beads in different culture media. There was an increase in $\mathrm{MnP}$ activity using Kirk medium supplemented with $\mathrm{MnSO}_{4} \mathrm{H}_{2} \mathrm{O}$ and wheat grain compared to the results obtained using Kirk medium supplemented with $\mathrm{MnSO}_{4} \mathrm{H}_{2} \mathrm{O}$ (without wheat grain). As shown above, the addition of wheat grain as lignocellulosic material favored the fungal growth and $\mathrm{MnP}$ production.

Using the tubes containing the glass beads, MnP activity reached the maximum value of $15.8 \mathrm{U} / \mathrm{L}$ day. The maximal activity using the Erlenmeyer flasks was $16.1 \mathrm{U} / \mathrm{L}$ day. The use of the tubes containing the glass beads for the cultivation of $A$. discolor $\mathrm{Sp} 4$ did not affect the $\mathrm{MnP}$ activity when using Kirk medium and $\mathrm{MnSO}_{4}$, as the values obtained did not differ largely from those in the Erlenmeyer flasks. When wheat grain was used as the substrate, $\mathrm{MnP}$ activity in the tubes was even higher than that in Erlenmeyer flasks ( $\mathrm{p} \leq 0.05)$, particularly for the days 12,15 and 19 after the inoculation. The MnP activity reached the maximum (956 U/L) after 19 days, 1.7-fold higher than that observed in the Erlenmeyer flasks after the same incubation period. In this case, $A$. discolor Sp4 covered all of the glass beads and 
wheat grains, which resulted in a larger contact surface area. When Tween 80 was used, no significant differences in the $\mathrm{MnP}$ activity were observed in the tubes containing glass beads or Erlenmeyer flaks.

Table 1 - Manganese peroxidase (MnP) activity (U/L) in A. discolor Sp4 cultures grown in Erlenmeyer flasks or tubes in different culture conditions. Values represent $\mathrm{MnP}$ activity mean $\mathrm{N}=3$. Asterisks (*) indicate a statistically significant difference between culture techniques at the same time ( $\mathrm{p}<0.05$, Student's t-test).

\begin{tabular}{|c|c|c|c|c|c|c|}
\hline \multirow{3}{*}{$\begin{array}{c}\text { Time } \\
\text { (days) }\end{array}$} & \multicolumn{6}{|c|}{ MnP activity (U/L) } \\
\hline & \multicolumn{2}{|c|}{$\begin{array}{c}\text { Kirk medium } \\
\text { Supplemented with } \\
\text { MnSO4.H2O } \\
\end{array}$} & \multicolumn{2}{|c|}{$\begin{array}{c}\text { Kirk medium supplemented } \\
\text { with } \mathrm{MnSO}_{4} \mathrm{H}_{2} \mathrm{O} \text { and wheat } \\
\text { grain }\end{array}$} & \multicolumn{2}{|c|}{$\begin{array}{c}\text { Kirk medium supplemented } \\
\text { with } \mathrm{MnSO}_{4} \mathrm{H}_{2} \mathrm{O} \text {, wheat grain and } \\
\text { Tween } 80\end{array}$} \\
\hline & Flask & Tube & Flask & Tube & Flask & Tube \\
\hline 4 & $2.4 \pm 0.2$ & $3.4 \pm 0.2$ & $4.5 \pm 1.6$ & $6.1 \pm 1.1$ & $3.4 \pm 1.9$ & $0.4 \pm 0.2$ \\
\hline 9 & $170 * \pm 19$ & $26^{*} \pm 1$ & $391 \pm 52$ & $357 \pm 76$ & $537 \pm 85$ & $320 \pm 130$ \\
\hline 12 & $57 * \pm 7$ & $191 * \pm 2$ & $425^{*} \pm 92$ & $779 * \pm 16$ & $630 \pm 157$ & $815 \pm 118$ \\
\hline 15 & $242 * \pm 27$ & $143 * \pm 26$ & $615^{*} \pm 134$ & $935^{*} \pm 111$ & $747 \pm 225$ & $769 \pm 29$ \\
\hline 19 & $101 \pm 11$ & $140 \pm 5$ & $547^{*} \pm 156$ & $956^{*} \pm 54$ & $696 * \pm 38$ & $969 * \pm 84$ \\
\hline 29 & $115^{*} \pm 17$ & $41 * \pm 19$ & $495 \pm 128$ & $276 \pm 81$ & $413 \pm 12$ & $96 \pm 0.4$ \\
\hline
\end{tabular}

Pizzul et al (2006) used the glass-beads tube technique to test the PAHs degradation by actinomycetes. The system allowed for both good microbial growth confined to the liquid medium and glass beads matrix and suitable and rapid PAH quantification with a PAHs recovery yield of up to $95 \%$. Glass beads also have been used to simulate the soil particles and monitor the growth of the mycorrhizal fungus Glomus intraradices (Rilling and Steinberg, 2002) and the actinobacterium Streptomyces (Nguyen et al, 2005). Ehlers and Rose (2005) evaluated the immobilization of three white-rot fungal cultures in trickling packed-bed reactors employing the glass beads as support in the biodegradation of phenol and 2,4,6trichlorophenol-contaminated liquid. Microscopic examination showed that the glass beads were colonized by the fungal cultures. Furthermore, rapid uptake, removal and biodegradation of the compounds were obtained as a result of the large contact surface area and long exposure to lignindegrading enzymes and mycelia (Ehlers and Rose, 2005).

\section{MnP purification}

$\mathrm{MnP}$ purification from A. discolor $\mathrm{Sp} 4$ cultivated under optimized culture conditions was carried out through two chromatographic steps: an anionexchange chromatography using a Q-Sepharose column coupled with further gel filtration chromatography using a GFC-100 column. Table 2 summarizes the results obtained from the MnP purification process. The MnP specific activity increased after each purification step, which suggested an increase in the MnP purity. In this study, a purification yield of approximately $48 \%$ was obtained after the anion-exchange chromatography but was reduced to $5.7 \%$ after the gel filtration chromatography step (Table 2). The purification factor increased from 4.35 to 4.70 after the second chromatographic step. This indicated that a single step with anion exchange chromatography was sufficient to obtain the purified MnP. After the first chromatographic step, fractions of elution volumes - 10, 10.5 and $11 \mathrm{~mL}$ - contained MnP activity (data not shown) and were collected and analyzed by the electrophoresis to determine the molecular mass of the protein. In the case of the second chromatographic step, two fractions (elution volumes of 5.5 and $6 \mathrm{~mL}$ ) contained MnP activity (data not shown), which also were collected and analyzed by the electrophoresis.

\section{MnP characterization}

The $\mathrm{K}_{\mathrm{M}}$ value, $\mathrm{pH}$ and optimum temperature values were determined in order to characterize the $\mathrm{MnP}$ produced by A. discolor $\mathrm{Sp} 4$. The apparent $\mathrm{K}_{\mathrm{M}}$ values of the purified MnP for 2,6-DMP and $\mathrm{H}_{2} \mathrm{O}_{2}$ were $25 \mu \mathrm{M}$ and $37 \mu \mathrm{M}$, respectively, indicating high affinity for both the substrates. Previous studies on kinetic parameters from Phanerochaete chrysosporium using 2,6-DMP as substrate have shown that $K_{M}$ values ranged from 7 to $29 \mu \mathrm{M}$ (Palma et al, 2000; Ürek and Pazarlioğlu, 2004) depending on the operational conditions and the isoenzymes produced. They were comparable and in the same magnitude order 
as the results obtained for the $\mathrm{MnP}$ enzyme from A. discolor. The $\mathrm{K}_{\mathrm{M}}$ values for Bjerkandera $\mathrm{sp}$. obtained using the same substrate showed a variation of between 11 and $121 \mu \mathrm{M}$, which could be considered a higher degradation rate than the $\mathrm{MnP}$ from A. discolor Sp4. Regarding kinetic parameters considering $\mathrm{H}_{2} \mathrm{O}_{2}$ as a substrate, earlier works have shownthat the $K_{M}$ values for
Phanerochaete chrysosporium ranged from 5 to 71 $\mu \mathrm{M}$ (Palma et al, 2000; Ürek and Pazarlioğlu, 2004) and were comparable to the results obtained for $\mathrm{MnP}$ from A. discolor $\mathrm{Sp} 4$. The $\mathrm{K}_{\mathrm{M}}$ values for Bjerkandera sp. obtained using the $\mathrm{H}_{2} \mathrm{O}_{2}$ showed a variation of between 3 and $5 \mu \mathrm{M}$ (Palma et al, 2000) which could be considered lower as compared with the $\mathrm{MnP}$ from A. discolor $\mathrm{Sp} 4$.

Table 2 - Purification process of MnP from A. discolor Sp4 in Kirk medium supplemented with wheat grain and $0.25 \mathrm{mM} \mathrm{MnSO}_{4}$ as inducer, incubated under static conditions at $30^{\circ} \mathrm{C}$. The $\mathrm{MnP}$ activity in the crude extracellular fluid and after the different steps were estimated by monitoring the oxidation of 2,6-DMP spectrophotometrically. Protein content was estimated by means of the Bradford method.

\begin{tabular}{cccccc}
\hline Purification step & $\begin{array}{c}\text { Total activity } \\
\text { (U) }\end{array}$ & $\begin{array}{c}\text { Total proteins } \\
\text { (mg) }\end{array}$ & $\begin{array}{c}\text { Specific activity } \\
(\mathbf{U} / \mathbf{m g})\end{array}$ & $\begin{array}{c}\text { Yield } \\
(\%)\end{array}$ & $\begin{array}{c}\text { Purification } \\
\text { fold }\end{array}$ \\
\hline Crude extracellular fluid & 109 & 18 & 6 & 100 & 1.0 \\
Ultrafiltration 10 kDa & 102 & 9 & 11 & 94 & 1.8 \\
Q Sepharose & 53 & 2 & 26 & 48 & 4.4 \\
Gel filtration GFC100 & 6 & 0.2 & 28 & 6 & 4.7 \\
\hline
\end{tabular}

The optimum $\mathrm{pH}$ range was between 4.5 and 5.5, with the relative activity dropping by $20 \%$ at $\mathrm{pH}$ 6.5 and being inactivated at $\mathrm{pH} 9.0$ (data not shown). This $\mathrm{pH}$ range was in agreement with the earlier reports (Ürek and Pazarlioğlu, 2004); nevertheless, a specific white-rot fungus (Aspergillus terreus LD-1) has been found to have an alkaline optimum $\mathrm{pH}$ range of between 11.0 and 12.5 (Kanayama et al, 2002).

The temperature required for maximize $\mathrm{MnP}$ production at $\mathrm{pH} 4.5$ was $50^{\circ} \mathrm{C}$ after $15 \mathrm{~min}$ of incubation, and the activity was completely lost at $70^{\circ} \mathrm{C}$ (data not shown). Temperatures for maximizing the $\mathrm{MnP}$ activity have been described from 22 (Paszczynski et al, 1988) to $60^{\circ} \mathrm{C}$ (Wang et al, 2002), depending on the fungus species. Activation energy (Ea) of $16.5 \mathrm{~kJ} / \mathrm{mol}$ was determined in the temperature range between 30 and $50^{\circ} \mathrm{C}$. This value was according to the $\mathrm{Ea}$ obtained for free enzymes such as invertase (20 $\mathrm{kJ} / \mathrm{mol}$ ) (Gianfreda et al, 1991) and urease from jack bean (13-15 kJ/mol) (Gianfreda et al, 1995). Regarding thermal stability, the MnP showed high stability between 40 and $50^{\circ} \mathrm{C}$ (Fig. 4). More than $95 \%$ activity was retained after $120 \mathrm{~min}$ of incubation at $40^{\circ} \mathrm{C}$. At $50^{\circ} \mathrm{C}, \mathrm{MnP}$ lost $30 \%$ of its activity after $2 \mathrm{~h}$ of incubation, reaching a value of $70 \%$ of its maximal activity (Fig. 4). In contrast, fast inactivation occurred at $60^{\circ} \mathrm{C}$ where the residual activity was $20 \%$ after $2 \mathrm{~h}$ of incubation and a sudden loss of activity was observed at $70^{\circ} \mathrm{C}$ where the activity decreased to zero after only 30 min of incubation. This indicated that the enzyme could be used in a broad temperature range due to its relatively high temperature tolerance.

\section{Molecular mass}

Two major bands were observed in the SDSPAGE gel after the purification, which suggested the presence of $\mathrm{MnP}$ isoenzymes $\left(\mathrm{MnP}_{1}\right.$ and $\mathrm{MnP}_{2}$ ) (Fig. 5a). The molecular mass of $\mathrm{MnP}$ isoenzymes was estimated to be 35 and $38 \mathrm{kDa}$ (Fig. 5b) by SDS-PAGE electrophoresis. The zymogram analysis of the purified enzyme sample confirmed the presence of two isoenzymes (Fig. $5 b)$. The molecular mass of the two isoenzymes was lower than those reported in the literature. The molecular mass range of the $\mathrm{MnP}$ in white-rot fungi is quite broad. Hofrichter (2002) reported a molecular mass from $38 \mathrm{kDa}$ for Trametes troggi up to $52.5 \mathrm{kDa}$ for Ceriporiopsis subvermispora.

The existence of multiple $\mathrm{MnP}$ isoenzymes in different ligninolytic fungi has been described (Lobos et al., 1994). The differences in the fungal species and strains and growth conditions (composition of the culture medium, incubation time, with or without agitation) strongly affect the isoenzyme patterns produced by the different fungi (Boer et al., 2006). Purification methods and storage also can affect the relative isoenzymatic levels (Cullen and Kersten, 1996). 


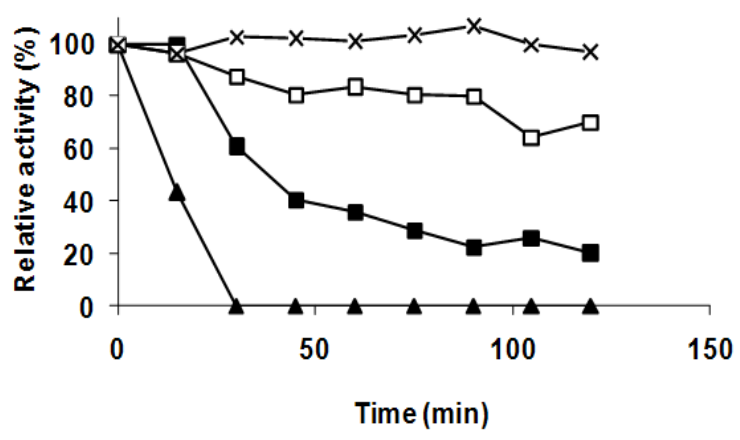

Figure 4 - Effect of temperature on $\mathrm{MnP}$ activity stability during $2 \mathrm{~h}$ of preincubation at $40^{\circ} \mathrm{C}(\mathrm{x})$, $50^{\circ} \mathrm{C}(\square), 60^{\circ} \mathrm{C}(\mathbf{\square}), 70^{\circ} \mathrm{C}(\boldsymbol{\Delta})$ at $\mathrm{pH} 4.5$.

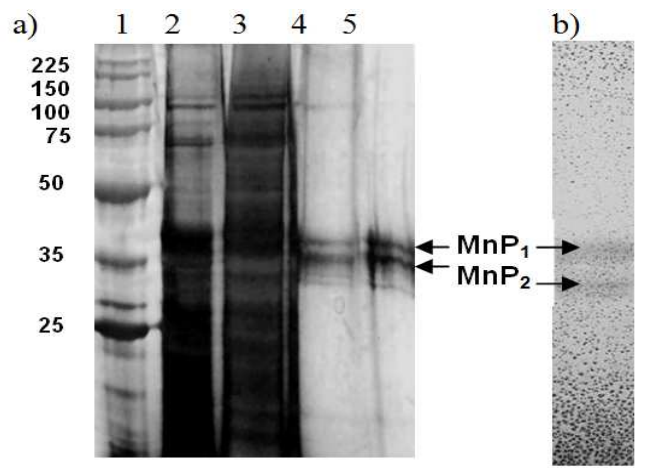

Figure 5 - a) Electrophoresis SDS-PAGE of MnP from A. discolor Sp4 with silver nitrate staining (1) proteins standards (Promega) (2) extracellular fluid (3) concentrate (4) after QSepharose column chromatogrphy (5) after gel filtration column chromatography b) Zymogram of MnP isoenzymes.

\section{CONCLUSIONS}

The results showed that the addition of wheat grain, $0.25 \mathrm{mM} \mathrm{MnSO}_{4}$ and $0.05 \%(\mathrm{v} / \mathrm{v})$ Tween 80 in Kirk medium significantly increased the MnP production from A. discolor Sp4. The enzyme produced by $A$. discolor $\mathrm{Sp} 4$ presented biochemical and kinetic properties, which could be quite advantagenous for the biodegradation purposes. The simple glass-bead technique used in this study in liquid medium allowed the growth of the fungal culture and enzyme production at the same levels compared to the standard Erlenmeyer flasks technique. This technique could be more practical in terms of space, resulted high $\mathrm{MnP}$ yields and simultaneously allowed a destructive sampling. The culture system in the tubes containing the glass beads could be considered a promising and suitable method for testing the bioremediation assays using the white-rot fungi.

\section{ACKNOWLEDGEMENTS}

This work was funded in part by FONDECYT project $\mathrm{N}^{\mathrm{o}} 1050614$, a doctoral scholarship from the CONICYT (Chile) and the Swedish Foundation for Strategic Environmental Research (MISTRA) through the funding for the Domestication of Microorganisms (DOM) Research Program and the Centre for Chemical Pesticides (CKB) at the Swedish University of Agricultural Sciences. The authors would like to thank Dr. Rodrigo Navia and Dr. María Elena Lienqueo for their suggestions.

\section{REFERENCES}

Bermek, H., Li, K., Eriksson, K.-E.L. (2002), Studies on inactivation and stabilization of manganese peroxidase from Trametes versicolor. In-Biotechnology in the pulp and paper industry 8th ICBPPI Meeting, Progress in Biotechnology, vol. 21, Elsevier Science., pp. 141-149 
Bradford, M.M. (1976), Rapid and sensitive method for the quantification of microgram quantities of protein utilizing the principle of protein-dye binding. Anal. Biochem., 72, 48-254

Boer, C., Obici, L., Souza, C., Peralta, R. (2006), Purification and some properties of Mn peroxidase from Lentinula edodes. Process Biochem. 42, 1203-1207

Cullen, D., Kersten, P.J. (1996), Enzymology and molecular biology of lignin degradation. In- Biochem. Mol. Biol., eds, R. Bramble, G.A. Marzluf. Berlin, Springer-Verlag, pp. 295-312

Dutton, M.V., Evans, C.S., Atkey, P.T., Wood, D.A. (1993) Oxalate production by basidiomycetes, including the white-rot species Coriolus versicolor and Phanerochaete chrysosporium. Appl. Microbiol. Biotechnol. 39, 5-10

Dutton, M.V., Evans, C.S. (1996), Oxalate production by fungi: its role in pathogenicity and ecology in the soil environment. Can J. Microbiol. 42, 881-895

Ehlers G.A., Rose P.D. (2005), Immobilized white-rot fungal biodegradation of phenol and chlorinated phenol in trickling packed-bed reactors by employing sequencing batch operation. Bioresour. Technol. 96, 1264-1275

Eibes, G., Cajthmal, T., Moreira, M.T., Feijoo, G., Lema, J.M. (2006), Enzymatic degradation of anthracene, dibenzothiophene and pyrene by manganese peroxidase in media containing acetone, Chemosphere, 64, 408-414

Garon, D., Krivobok, S., Wouessidjewe, D., SeigleMurandi, F. (2002) Influence of surfactants on solubilization and fungal degradation of fluorene. Chemosphere. 47, 303-309

Gianfreda, L., Rao, M.A., Violante, A. (1991) Invertase $(\beta)$-fructosidase: effects of montmorillonite, Alhydroxide and $\mathrm{Al}(\mathrm{OH}) \mathrm{x}$-montmorillonite complex on activity and kinetic properties. Soil Biol. Biochem. 23, 581-587

Gianfreda, L., De Cristofaro, A.D., Rao, M.A., Violante, A. (1995), Kinetic behavior of synthetic organo- and organo-mineral complexes. Soil Sci. Soc. Am. J. 59, 811815

Giardina, P., Palmieri, G., Fontanella, B., Riviecco, V., Sannia, G. (2000), Manganese peroxidase isoenzymes produced by Pleurotus ostreatus grown on wood sawdust. Arch. Physiol. Biochem. 376, 171-179

Gill, P.K., Arora, D.S. (2003), Effect of culture conditions on manganese peroxidase production and activity by some white rot fungi. J. Ind. Microbiol. Biotechnol. 30, 28-33

Gómez-Toribio, V., Martínez, A.T., Muñoz, M.J., Guillén, F. (2001), Oxidation of hydroquinones by the versatile ligninolytic peroxidase from Pleurotus eryngii. Eur. J. Biochem. 268, 4787-4793

Herpoël, I., Asther, M., Sigoillot, J-C. (1999), Design and scale up of a process for manganese peroxidase production using the hypersecretory strain Phanerochaete chrysosporium I-1512. Biotechnol. Bioeng. 65, 468-473

Hofrichter, M. (2002), Review: Lignin conversion by manganese peroxidase (MnP). Enzyme Microb. Technol. 30, $454-466$
Kanayama, N., Tohru, S., Keiichi, K. (2002), Purification and characterization of an alkaline manganese peroxidase from Aspergillus terreus LD-1. J. Biosci. Bioeng. 93, 405-410

Kapich, A.N., Prior, B.A., Botha, A., Galkin, S., Lundell, T., Hatakka, A. (2004), Effect of lignocellulosecontaining substrates on production of ligninolytic peroxidases in submerged cultures of Phanerochaete chrysosporium ME-446. Enzyme Microb. Technol. 34, 187-195

Kuan, I.C., Tien, M. (1993), Stimulation of Mn peroxidase activity: a possible role for oxalate in lignin biodegradation. Proc. Natl. Acad. Sci .U.S.A. 90, 12421246

Laemmi, U.K. (1970), Cleavage of structural proteins during the assembly of the head of bacteriophage T4. Nature. 227, 680-685

Lobos, S., Larraín, J., Salas, L., Cullen, D., Vicuña, R. (1994), Isoenzymes of manganese-dependent peroxidase and laccase produced by the lignin-degrading basidiomycete Ceriporiopsis subvermispora. Microbiology 140, 2691-2698

Ma, B., Mayfield, M.B., Godfrey, B.J., Gold, M.H. (2004), Novel promoter sequence required for manganese regulation of manganese peroxidase isozyme 1 gene Expression in Phanerochaete chrysosporium. Eukaryotic Cell. 3, 579-588

Mäkelä, M., Galkin, S., Hatakka, A., Lundell, T. (2002), Production of organic acids and oxalate decarboxylase in lignin-degrading white rot fungi. Enzyme Microb. Technol. 30, 542-549

Mester, T., Tien, M. (2000), Oxidation mechanism of ligninolytic enzymes involved in the degradation of environmental pollutants. Int. Biodeterioration Biodegrad. 46, 51-59

Moredo, N., Lorenzo, M., Domínguez, A., Moldes, D., Cameselle, C., Sanroman, A. (2003), Enhanced ligninolytic enzyme production and degrading capability of Phanerochaete chrysosporium and Trametes versicolor. World J. Microbiol. Biotechnol. 19, 665-669

Nguyen, L.D., Kalachová, L., Novotná, J., Holub, M., Kofronǒvá, O., Benada, O., Thompson, C.J., Weiser, J. (2005), Cultivation system using glass beads immersed in liquid medium facilitates studies of streptomyces differentiation. Appl. Environ. Microbiol. 71, 28482852.

Palma, C., Martínez, A.T., Lema, J.M., Martínez, M.J. (2000), Different fungal manganese-oxidizing peroxidases: a comparison between Bjerkandera sp. and Phanerochaete chrysosporium. J. Biotechnol. 77, 235245.

Paszczynski, A., Crawford, R.L., Huynh, V.B. (1988), Manganese peroxidase from Phanerochaete chrysosporium: Purification. In-Methods in Enzymology. Biomass Part B: Lignin, Pectin, and Chitin, ed. W.A. Wood, S.T. Kellogg. USA, Elsevier, 161, pp. 264-270

Pizzul, L., Castillo, M.dP., Stenström, J. (2006), Characterization of selected actinomycetes degrading polyaromatic hydrocarbons in liquid culture and spiked soil. World J. Microbiol. Biotechnol. 22,745-752 
Pointing, S. (2001), Feasibility of bioremediation by white-rot fungi. Appl. Environ. Microbiol. 57, 20-33

Rabinovich, M.L., Bolobova, A.V., Vasilchenko, L.G. (2003), Fungal decomposition of natural aromatic structures and xenobiotic: a review. Appl. Biochem. Microbiol. 40, 1-18

Rao, M.A., Gianfreda, L. (2000), Properties of acid phosphatase-tannic acid complexes formed in the presence of Fe and Mn. Soil Biol. Biochem. 32, 19211926

Rilling, M.C., Steinberg, P.D. (2002), Glomalin production by an arbuscular mycorrhizal fungus: a mechanism of habitat modification? Soil Biol. Biochem. 34, 1371-1374

Rogalski, J., Szczodrak, J., Janusz, G. (2006), Manganese peroxidase production in submerged cultures by free and immobilized mycelia of Nematoloma frowardii. Bioresour. Technol. 27, 469-476

Rothschild, N., Levkowitz, A., Hadar, Y., Dosoretz, C. (1999), Manganese deficiency can replace high oxygen levels needed for lignin peroxidase formation by Phanerochaete chrysosporium. Appl. Environ. Microbiol. 65, 483-488

Rowley, B.I., Bull, A.T. (1977), Isolation of a yeast-lyzing Arthrobacter species and the production of the lytic enzyme complex in batch and continous flow fermentors. Biotechnol. Bioeng. 19, 879-899

Rubilar, O., Feijoo, G., Diez, M.C., Lu-Chan, T.A., Moreira, M.T., Lema, J.M. (2007), The application of white rot fungi for the bioremediation of pentachlorophenol (PCP) in soil slurry cultures. Ind. Eng. Chem. Res. 46, 6744-6751

Sato, S., Liu, F., Koc, H., Tien, M. (2007), Expression analysis of extracellular proteins from Phanerochaete chrysosporium grown on different liquid and solid substrates. Microbiology. 153, 3023-3033

Schlosser, D., Höfer, C. (2002), Laccase-catalyzed oxidation of $\mathrm{Mn}^{2+}$ in the presence of natural $\mathrm{Mn}^{3+}$ chelators as a novel source of extracellular $\mathrm{H}_{2} \mathrm{O}_{2}$ production and its impact on manganese peroxidase. Appl. Environ. Microbiol. 68, 3514-3521

Staszczak, M., Zdunek, E., Leonowicz, A. (2000), Studies on the role of proteases in the white-rot fungus Trametes versicolor: Effect of PMSF and chloroquine on ligninolytic enzymes activity. J. Basic Microbiol. 40, 51-63

Tien, M., Kirk, T.K. (1988), Lignin Peroxidase of Phanerochaete chrysosporium. In-Methods in Enzymology, Biomass Part B: Lignin, Pectin, and Chitin, eds.Wood, W.A., Kellogg, S.T. USA, Elsevier, 161, pp. 238-249

Tortella, G.R., Rubilar, O., Gianfreda, L., Valenzuela, E., Diez, M.C. (2008), Enzymatic characterization of Chilean native wood-rotting fungi for potential use in biotechnology applications. World J. Microbiol. Biotechnol. 24, 2805-2818

Ürek, R.Ö., Pazarlioğlu, N.K. (2004), Purification and partial characterization of manganese peroxidase from immobilized Phanerochaete chrysosporium. Process Biochem. 39, 2061-2068
Ürek, R.Ö., Pazarlioğlu, N.K. (2005), Production and stimulation of manganese peroxidase by immobilized Phanerochaete chrysosporium. Process Biochem. 40, 83-87

Ürek, R.Ö., Pazarlioğlu, N.K. (2007), Enhanced production of manganese peroxidase by Phanerochaete chrysosporium. Braz. Arch. Biol. Techn. 50, 913-920

Urzúa, U., Kersten, P., Vicuña, R. (1998), Manganese peroxidase-dependent oxidation of glyoxylic and oxalic acids synthesized by Ceriporiopsis subvermispora produces extracellular hydrogen peroxide. Appl. Environ. Microbiol. 64, 68-73

Van den Wymelenberg, A., Minges, P., Sabat, G., Martinez, D., Aerts, A., Salamov, A., Grigoriev, I., Shapiro, H., Putnam, N., Belinky, P., Dosoretz, C., Gaskell, J., Kersten, P., Cullen, D. (2006), Computational analysis of the Phanerochaete chrysosporium v2.0 genome database and mass spectrometry identification of peptides in ligninolytic cultures reveal complex mixtures of secreted proteins. Fungal Genet. Biol. 43, 343-356

Venkatadri, R., Irvine, R.L. (1990), Effect of agitation on ligninase activity and ligninase production by Phanerochaete chrysosporium. Appl. Environ. Microbiol. 56, 2684-2691

Wang, Y., Vazquez-Duhalt, R., Pickard, M.A (2002), Purification, characterization, and chemical modification of manganese peroxidase from Bjerkandera adusta UAMH 8258. Curr. Microbiol. 45, 77-87

Wariishi, H., Valli, K., Gold, M.H. (1992), Manganese (II) oxidation by manganese peroxidase from the basidiomycetes Phanerochaete chrysosporium. Kinetic mechanism and role of chelators. J. Biol. Chem. 267, 23688-23695

Wariishi, H., Akileswaran, L., Gold, M.H. (1988), Manganese peroxidase from Phanereochaete chrysosporium: spectral characterization of the oxidized states and the catalytic cycle. Biochemistry. 27, 53655370

Watanabe, T., Katayama, S., Enoki, M., Honda, Y., Kuwahara, M. (2000), Formation of acyl radical in lipid peroxidation of linoleic acid by manganese-dependent peroxidase from Ceriporiopsis subvermispora and Bjerkandera adusta. Eur. J. Biochem. 267, 4222-4231

Whiteley, C.G., Lee, D-J. (2006), Review: Enzyme technology and biological remediation. Enzyme Microb. Technol. 38, 291-316

Zheng, Z., Obbard, J.P. (2002), Polycyclic aromatic hydrocarbon removal from soil by surfactant solubilization and Phanerochaete chrysosporium oxidation. J. Environ. Qual. 31, 1842-1847

Zhou, J., Jiang, W., Ding, J., Zhang, X., Gao, S. (2007), Effect of Tween 80 and b-cyclodextrin on degradation of decabromodiphenyl ether (BDE-209) by white rot fungi. Chemosphere. 70, 172-177

Received: June 21, 2010; Revised: January 20, 2010; Accepted: August 09, 2011. 